Financialisation and the slowdown of labour productivity in Portugal:

A post-Keynesian approach

Diogo Correia

Ricardo Barradas

Novembro de 2021

WP n. ${ }^{\circ} 2021 / 07$

DOCUMENTO DE TRABALHO

WORKING PAPER

dinamia 'cet_iscte

Centro de Estudos sobre a Mudança

Socioeconómica e o Território

iscte

FCT 


\section{dinamia "cet_iscte}

Financialisation and the slowdown of labour productivity in Portugal:

A post-Keynesian approach

Diogo Correia*

Ricardo Barradas**

WP n. $\circ 2021 / 07$

DOI: $10.15847 /$ dinamiacet-iul.wp.2021.07

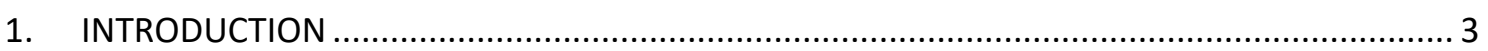

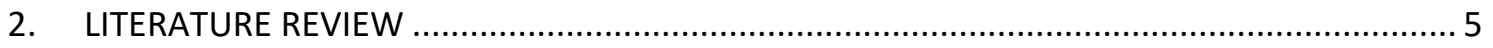

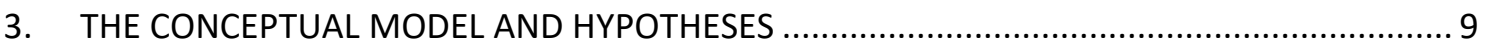

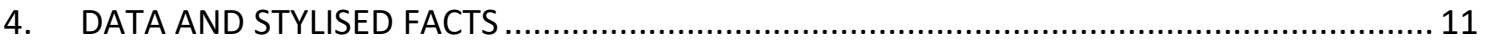

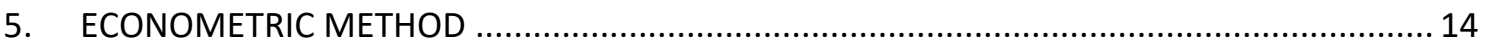

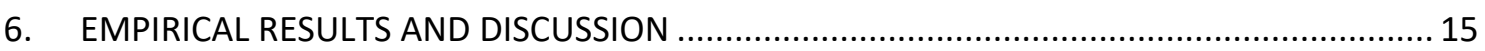

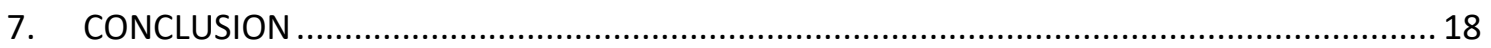

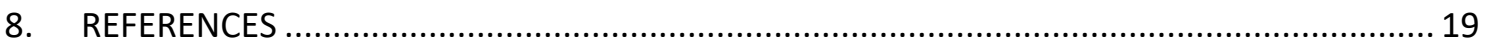

* Caixa Geral de Depósitos, Lisboa, Portugal. E-mail: diogoscorreia2202@gmail.com

** Iscte - Instituto Universitário de Lisboa, DINÂMIA'CET - Iscte, Lisboa, Portugal. ISCAL - Instituto Superior de Contabilidade e Administração de Lisboa, Instituto Politécnico de Lisboa, Lisboa, Portugal. Email: ricardo barradas@iscte-iul.pt (corresponding author) 


\title{
Financialisation and the slowdown of labour productivity in Portugal: A post-Keynesian approach ${ }^{1}$
}

\begin{abstract}
The aim of this paper is to conduct a time series econometric analysis in order to empirically evaluate the role of financialisation in the slowdown of labour productivity in Portugal during the period from 1980 to 2017. During that time, the Portuguese economy faced a financialisation phenomenon due to the European integration process and the corresponding imposition of a strong wave of privatisation, liberalisation and deregulation of the Portuguese financial system. At the same time, Portuguese labour productivity exhibited a sustained downward trend, which seems to contradict the well-entrenched mainstream hypothesis on the finance-productivity nexus. Based on the post-Keynesian literature, we identify four channels through which the phenomenon of financialisation has impaired labour productivity, namely weak economic performance, the fall in labour's share of income, the rise of inequality in personal income and an intensification of the degree of financialisation. The paper finds that lagged labour productivity, economic performance and labour income share positively impact labour productivity in Portugal, while personal income inequality and the degree of financialisation negatively impact labour productivity in Portugal. The paper also finds that the main triggers for the slowdown of labour productivity in Portugal are the degree of financialisation and personal income inequality over the last decades.
\end{abstract}

Keywords: Portugal, Labour Productivity, Financialisation, Time Series, Generalised Method of Moments.

JEL CLASSIFICATION: C22, E12, E24, and E44

\footnotetext{
${ }^{1}$ The authors thank the helpful comments and suggestions of Alexandra Ferreira-Lopes, Helena Lopes and Sérgio Lagoa. The usual disclaimer applies.
} 


\section{INTRODUCTION}

The adhesion of Portugal to the European Economic Community in 1986 forced the adoption of a strong wave of privatisation, liberalisation and deregulation of the Portuguese financial system (Barradas et al., 2018). According to these authors, these measures were imposed as an excuse to promote a decrease in financial repression and an increase in financial development in order to foster a better allocation of savings to investment and support stronger economic growth (Levine, 1997; Dua and Garg, 2019). Nonetheless, economic growth and labour productivity in Portugal have denoted a strong deceleration since that time, which seems to contradict the well-rooted mainstream hypotheses on the finance-growth nexus and on the finance-productivity nexus.

This phenomenon, typically called financialisation, emphasises a negative role of the financial system, mainly in a strong liberalising and deregulatory environment. Indeed, postKeynesian scholars have highlighted that the slowdown of labour productivity in more advanced economies in the last decades cannot be dissociated from the phenomenon of financialisation, which has occurred through four different channels (Tridico and Pariboni, 2018), namely weak economic performance, a fall in the labour income share, the rise of personal income inequality and the intensification of the degree of financialisation.

From an empirical point of view, several works have emerged which assess the determinants of labour productivity (Fortune, 1987; Vergeer and Kleinknecht, 2014; Micallef, 2016; Tridico and Pariboni, 2018; Dua and Garg, 2019; Pariboni and Tridico; 2020; Carnevali et al., 2020; Yousef, 2020). However, the majority of these empirical works do not assess all four channels through which the phenomenon of financialisation has impaired labour productivity. The empirical work of Tridico and Pariboni (2018) is the only exception. They estimated an extended version of the aggregate equation of labour productivity presented by Labini (1984, 1999) and concluded that economic performance and labour income share exert a positive effect on labour productivity in the Organisation for Economic Cooperation and Development (OECD) countries, while personal income inequality and the degree of financialisaton exert a negative effect on labour productivity in these countries.

This paper aims to conduct a time series econometric analysis in order to empirically evaluate the role of these four channels linked to the phenomenon of financialisation on the slowdown of labour productivity in Portugal during the period from 1980 to 2017. This paper contributes to the existing literature in at least four different ways. First, this paper is only focused on Portugal. Portugal is a very interesting case study due to the sustained downward trend in the evolution of labour productivity in the last decades (Figure 1), which has simultaneously occurred with the phenomenon of financialisation. Labour productivity in Portugal is at one of the lowest levels among the European Union countries, only surpassing labour productivity in Greece, 
Poland, Romania, Latvia and Bulgaria. Second, this paper performs a time series econometric analysis in a context in which the majority of empirical works on labour productivity have conducted a panel data econometric analysis and, therefore, reach conclusions that are just an average effect of each determinant on several countries as a whole. The time series econometric analysis allows us to overcome this shortcoming by facilitating our understanding of the historical, social, economic and institutional circumstances that are responsible for the evolution of labour productivity in a specific country over time. Third, this paper uses five different variables to proxy the degree of financialisation, namely credit, money supply, financial value added, stock market capitalisation and shareholder orientation. Tridico and Pariboni (2018) only used stock market capitalisation to proxy the degree of financialisation. Our approach allows us to take into account the different dimensions related to financialisation (e.g., size, depth and efficiency) played by different financial intermediaries (e.g., banks and stock markets) or even by shareholders (Barradas, 2021). Fourth, this paper assesses not only the determinants of labour productivity in Portugal, which is the traditional strategy used by the majority of empirical works related to this matter, but also the correspondent drivers. This allows us to identify the contribution of each determinant to the evolution of labour productivity in Portugal in the last decades (McCloskey and Ziliak, 1996; Ziliak and McCloskey, 2004).

The paper estimates an aggregate equation according to which labour productivity depends on lagged labour productivity, economic performance, the labour income share, personal income inequality and the degree of financialisation. The Generalised Method of Moments (GMM) estimator was employed due to the inclusion of lagged labour productivity among the remaining independent variables and to contour the potential problem of endogeneity that arises when we have problems with omitted variables and/or simultaneity among our variables.

The paper concludes that lagged labour productivity, economic performance and labour income share exert a positive impact on labour productivity in Portugal, whereas personal income inequality and the degree of financialisation exert a negative impact on labour productivity in Portugal. The paper also concludes that the degree of financialisation and personal income inequality have been the main drivers of the slowdown in labour productivity in Portugal in the last decades.

The remainder of the paper is organised as follows. In Section 2, we provide a literature review on the channels through which financialisation impairs labour productivity. Section 3 presents the conceptual model and the respective hypotheses. Data and the stylised facts are described in Section 4. In Section 5, we explain the econometric method. The empirical results are discussed in Section 6. Finally, Section 7 concludes. 


\section{LITERATURE REVIEW}

It is widely recognised that the majority of the advanced economies have suffered a colossal transformation since the end of the mid-1970s, mainly due to a strong financial liberalising and deregulatory environment. Barradas (2016) highlighted that the emergence of this new paradigm was fostered on the theoretical and empirical grounds of the advantages provided by larger and deeper financial systems. Several policy measures have been widely adopted at a country level since that time, such as the elimination of administrative controls on the functioning of the financial system, the reduction of legal reserve requirements, the creation of new and more financial institutions and the corresponding privatisation of the existing ones, the appearance of new financial products and/or services and the elimination of controls on international capital flows (Ang, 2008; Sawyer, 2014, 2015; Ehigiamusoe and Lean 2017).

Consequently, the financial system has acquired great supremacy in more advanced economies and has given rise to an excessive financial deepening with harmful effects on the real economy and on general society which is mainly visible in the higher incidences of financial crises, the emergence of inflation episodes, a larger vulnerability of banking systems, a greater volatility in the aggregate demand and an increased financial instability due to more recurring financial bubbles and bursts in the last decades (Rousseau and Wachtel, 2011; Barajas et al., 2013; Dabla-Norris and Srivisal, 2013; Tridico and Pariboni, 2018). This reflects a negative view on the current role of the financial system, a phenomenon that is commonly called financialisation.

Moreover, the phenomenon of financialisation has simultaneously occurred with a sustained downward trend in labour productivity in the more advanced economies since the end of the mid-1970, which seems to suggest that they could be interrelated. This contradicts the wellentrenched mainstream hypothesis on the finance-productivity nexus due to the role that the financial system plays in the allocation of savings to investment opportunities and in technological progress (Levine, 1997; Dua and Garg, 2019). Indeed, the post-Keynesian literature tends to highlight that the slowdown in labour productivity in more advanced economies in the last decades cannot be dissociated from the phenomenon of financialisation which has occurred through four different channels (Tridico and Pariboni, 2018), notably weak economic performance, a fall in the labour income share, a rise in personal income inequality and an intensification of the degree of financialisation. In what follows, we describe each of these four channels in detail as well as the connection of each to labour productivity.

The first channel is linked with an indirect effect between the phenomenon of financialisation, economic performance and labour productivity. The post-Keynesian argument is 
that the phenomenon of financialisation has favoured weaker economic growth ${ }^{2}$, which has contributed to sluggish labour productivity through the so-called 'Smith effect' (1776) or the 'Classical Kaldorian-Verdoorn effect' (Verdoorn, 1949; Kaldor, 1961). This effect sustains that labour productivity positively depends on economic growth due to the increasing returns to scale (Kaldor, 1957). According to Labini (1999) and Carnevali et al. (2020), this effect also captures the extent of the market which, in turn, influences the division of labour by allowing workers to focus on and specialise in specific tasks, thereby promoting an increase in labour productivity.

The second channel is connected to an indirect effect among the phenomenon of financialisation, labour income share and labour productivity. The post-Keynesian argument is that the phenomenon of financialisation has contributed to a fall in the labour income share ${ }^{3}$, which has promoted a slowdown in labour productivity through the so-called 'Webb-Sylos Labini effect' (Labini, 1984, 1999) or 'the Marx and Hicks effect' (Hein and Tarassow, 2010). This effect establishes a positive relationship between labour income share and labour productivity for six different reasons. The first reason is that an increase in labour income share represents an incentive for a more efficient organisation of the production process and for the adoption of new technological investments in order to lower production costs; this allows an increase in production even without an increase in the number of workers and the corresponding acceleration of labour productivity (Webb, 1912; Labini, 1984, 1999; Altman, 1998). This is the so-called 'organisation effect' (Carnevali et al., 2020). Second, an increase in labour income share reduces the ' $x$ inefficiencies' by favouring an improvement in working conditions, the establishment of more cooperative labour relations, higher motivation and lower levels of turnover which are reflected in greater discipline and effort by the workers and an acceleration of labour productivity (Altman, 1998). This is the so-called 'wage-efficiency effect' (Tridico and Pariboni, 2018). Third, an increase in the labour income share tends to attract highly productive workers and encourage them to be more efficient, which sustains an acceleration of labour productivity (Carnevali et al., 2020). This is the so-called 'Marshall effect' (Marshall, 1890). The fourth reason is that an increase in labour income share forces a higher propensity to save, which supports new investments and the corresponding acceleration of the labour productivity (Altman, 1998). This is the so-called 'savings effect' (Altman, 1998). Fifth, an increase in labour income share drives 'natural selection' or 'creative destruction' in a context in which routine corporations and/or laggards are

\footnotetext{
${ }^{2}$ Barradas (2020) explains in detail why there has been a negative relationship between the phenomenon of financialisation and economic growth in the last decades, which has been confirmed by the emergence of several empirical works that have found a reversal of the traditional hypothesis of the finance-growth nexus (Rioja and Valev, 2004a, 2004b; Aghion et al., 2005; Kose et al., 2006; Prasad et al., 2007; Rousseau and Wachtel, 2011, Cecchetti and Kharroubi, 2012; Barajas et al., 2013; Dabla-Norris and Srivisal, 2013; Beck et al., 2014; Breintenlechner et al., 2015; Alexiou et al., 2018; Ehigiamusoe and Lean, 2018; Barradas, 2020).

${ }^{3}$ Hein (2012), Barradas and Lagoa (2017), Barradas (2019) and Kohler et al. (2019) describe how the phenomenon of financialisation has contributed to the fall in labour income share in the last few decades. Kristal (2010), Dünhaupt (2013), Lin and TomaskovicDevey (2013), Alvarez (2015), Barradas and Lagoa (2017), Stockhammer (2017), Barradas (2019) and Kohler et al. (2019) are examples of empirical works that have found a negative relationship between the phenomenon of financialisation and labour income share.
} 
thrown out of the market and the most innovative ones face the opportunity to increase their own market share by contributing to the growth of labour productivity as a whole (Carnevali et al., 2020). The final reason is that an increase in the labour income share supports higher economic growth, particularly in countries that follow 'wage-led growth models' (Onaran and Obst, 2016), which contributes to an acceleration of labour productivity through the aforementioned 'Smith effect' or the 'Classical Kaldorian-Verdoorn effect'.

The third channel is associated with an indirect effect among the phenomenon of financialisation, personal income inequality and labour productivity. The post-Keynesian argument is that the phenomenon of financialisation has induced a rise in personal income inequality ${ }^{4}$ which, in turn, has contributed to a deceleration of labour productivity due to workers putting less effort into their jobs (Tridico and Pariboni, 2018) in a context of higher vulnerability of unskilled labour and/or low-skilled labour and less confidence in job stability (Vergeer and Kleinknecht, 2014) in line with more unstable (and precarious) jobs, higher flexibility, scarcer incentives and lower paid jobs (Pariboni and Tridico, 2020). These trends also discourage an investment in training and education by workers, which directly affects labour productivity (Pariboni and Tridico, 2020). In effect, the abandonment of full employment goals, the proliferation of 'shareholder value orientation', an excessive managerial focus on short-term profitability, the emergence of multinational corporations that systematically threaten to relocate their production to low-wage countries, the deregulation and flexibilisation of labour markets (at the level of unemployment benefits, employment protection, employment rights and minimum wage), the emergence of practices such as outsourcing, the rise of precarious labour conditions and unproductive work and the deterioration of the general workers' bargaining power have promoted a rise in personal income inequality, a fall in the labour income share, weaker economic growth and a slowdown in labour productivity (Tridico and Pariboni, 2018).

The fourth channel is related to a direct effect between the degree of financialisation and labour productivity (Hein, 2010). This effect ascertains a negative relationship between the phenomenon of financialisation and innovation, technological progress, research and development and real investment by corporations which directly affects labour productivity. According to post-Keynesian literature, and as emphasised by Orhangazi (2008), Hein and van Treeck (2010) and Hein (2012), the phenomenon of financialisation has impaired real investment realised by corporations for two different reasons. The phenomenon of financialisation has led to

\footnotetext{
${ }^{4}$ Lagoa and Barradas (2020) clarified to what extent the phenomenon of financialisation has exerted a positive impact on personal income inequality in the last decades, which has been corroborated by the emergence of several empirical works that have found a positive relationship between the phenomenon of financialisation and personal income inequality (Greenwood and Jovanovic, 1990; Banerjee and Newmann, 1993; Galor and Zeira, 1993; Baldacci et al., 2002; Roine et al., 2009; Atkinson and Morelli, 2011; Gimet and Lagoarde-Segot, 2011; Assa, 2012; Fournier and Koske, 2012; Jauch and Watzka, 2012; Jaumotte et al., 2013; Karanassou and Sala, 2013; Denk and Cournede, 2015; Furceri and Loungani, 2015; Jaumotte and Buitron, 2015; Han and Sturm, 2017; Baiardi and Morana, 2018).
} 
an increase in financial investments by corporations, which has diverted funds from real investment. This is the so-called 'crowding out effect' or 'management's preference channel' (Hein, 2012) which is due to shorter planning horizons (Crotty, 2005) and the corresponding 'managerial myopia' (Samuel, 2000); the increasing concern with short-term profits (so-called 'rent-seeking behaviour') instead of long-term expansion (Orhangazi, 2008); the downward trend of profits from the real sector and the increase in external funding costs that has occurred since the 1980's (Crotty, 2005; Orhangazi, 2008; Baud and Durand, 2012); higher macroeconomic uncertainty and heightened risks (Akkemik and Özen, 2014); the learning process with other corporations (the so-called 'mimetic behaviour') and the influence of some agents (financial executives or independent consultants) on the advantages provided by the realisation of financial investments (Soener, 2015). The phenomenon of financialisation has also intensified the pressure exerted upon corporations to increase financial payments (interest, dividends and/or stock buybacks) in order to satisfy impatient shareholders, which has promoted lower retention ratios and decreased the available funds for real investment due to the 'principle of increasing risk' (Kalecki, 1937) and the corresponding difficulty to access external funding in an environment of imperfect capital markets (Hein, 2010). This is the so-called 'profit without investment' hypothesis (Stockhammer, 2006; Cordonnier and Van de Velde, 2015) or the 'internal means of finance channel' (Hein, 2012) which is due to higher levels of corporate indebtedness (Orhangazi, 2008), the existence of remuneration schemes based on profits (Orhangazi, 2008), the higher importance of institutional investors (Orhangazi, 2008) and the proliferation of a new design of corporate governance that privileges the maximisation of shareholder value (the so-called 'shareholder value orientation') rather than other corporations' stakeholders (Lazonick and O’Sullivan, 2000). Stockhammer (2004), Orhangazi (2008), van Treeck (2008), Onaran et al. (2011), Seo et al. (2012), Barradas (2017), Barradas and Lagoa (2017), Davis (2017) and Tori and Onaran $(2018,2019)$ are examples of empirical works that confirm a harmful effect from the phenomenon of financialisation on real investment by corporations.

Fortune (1987), Vergeer and Kleinknecht (2014), Micallef (2016), Tridico and Pariboni (2018), Dua and Garg (2019), Pariboni and Tridico (2020), Carnevali et al. (2020) and Yousef (2020) are examples of several empirical works on the determinants of labour productivity. Nonetheless, they do not take into account all four of the aforementioned channels through which the phenomenon of financialisation has contributed to the slowdown of labour productivity in more advanced economies. The study by Tridico and Pariboni (2018) is the only exception. These authors performed a panel data econometric analysis of 26 countries in the OECD (Australia, Austria, Belgium, Canada, Chile, Denmark, Finland, France, Germany, Greece, Iceland, Israel, Italy, Japan, Luxembourg, Mexico, the Netherlands, New Zealand, Norway, Portugal, Republic of Korea, Spain, Sweden, Switzerland, the United Kingdom and the United States) during the 
period from 1990 to 2013. They concluded that the labour productivity of these countries positively depends on economic performance and on labour income share and negatively depends on personal income inequality and on the degree of financialisation. A positive relationship between economic performance and labour productivity was also found by Carnevali et al. (2020) and a positive relationship between labour income share and labour productivity was also found by Vergeer and Kleinknecht (2014), Carnevali et al. (2020) and Yousef (2020). To the best of our knowledge, personal income inequality and the degree of financialisation have been quite neglected in the empirical evidence on the determinants of labour productivity, other than with the exception of the aforementioned empirical work performed by Tridico and Pariboni (2018).

Similar to the empirical work carried out by Tridico and Pariboni (2018), this paper aims to address the effects of these four channels linked to the phenomenon of financialisation on labour productivity in Portugal by conducting a time series econometric analysis covering the period from 1980 to 2017.

\section{THE CONCEPTUAL MODEL AND HYPOTHESES}

Our conceptual model is based on an aggregate equation according to which labour productivity depends on lagged labour productivity, economic performance, labour income share, personal income inequality and the degree of financialisation. Our conceptual model is quite similar to the model proposed by Tridico and Pariboni (2018) and, therefore, also represents an extension of the aggregate equation of labour productivity presented by Labini $(1984,1999)$.

Contrary to the model presented by Labini $(1984,1999)$ but analogously to the model proposed by Tridico and Pariboni (2018), we do not include in our aggregate equation of labour productivity the cost of labour in relation to the price of investment goods, that is, the so-called 'Ricardo effect' (Ricardo, 1821), for three different reasons. First, there is no available data in order to properly assess the importance of this effect in the specific case of Portugal. Second, the role of this effect on labour productivity is rather similar to the effect exerted by labour income share, that is, the aforementioned 'Webb-Sylos Labini effect' (Labini, 1984, 1999) or 'the Marx and Hicks effect' (Hein and Tarassow, 2010). The former reflects the relative impact of labour costs on labour productivity and the latter translates the absolute impact of labour costs on labour productivity. But both of them will induce a technological change if an increase in labour costs occurs in order to prevent an increase in production costs which will, in turn, stimulate an acceleration of labour productivity (Tridico and Pariboni, 2018). Third, the validity of the 'Ricardo effect' is too limited in that it requires several assumptions to be made about the available set of production methods from which producers can choose and it is restricted to an extremely special case (Gehrke, 2003). 
Against this backdrop, our conceptual model of labour productivity takes the following form:

$$
L P_{t}=\beta_{0}+\beta_{1} L P_{t-1}+\beta_{2} E P_{t}+\beta_{3} L I S_{t}+\beta_{4} P I I_{t}+\beta_{5} D F_{t}+\alpha_{t}
$$

where $t$ is the time period (years), LP is the growth rate in labour productivity, EP is the growth rate in economic performance, LIS is the labour income share, PII is personal income inequality, DF is the degree of financialisation and $\alpha$ is an independent and identically distributed (whitenoise) disturbance term with a null average and constant variance (homoscedastic).

We included in our conceptual model the lag of the dependent variable, which means the inclusion of lagged labour productivity among the remaining independent variables. The objective is to take into account the potential persistence degree exhibited by labour productivity and to control for state dependency (Vergeer and Kleinknecht, 2014).

According to our previously described arguments, we expect that lagged labour productivity, economic performance and labour income share exert a positive influence on labour productivity, while personal income inequality and the degree of financialisation exert a negative influence on labour productivity. Our hypotheses suggests that the estimated coefficients should present the following signs:

$$
\beta_{1}>0, \beta_{2}>0, \beta_{3}>0, \beta_{4}<0, \beta_{5}<0
$$

Note that we are proposing to estimate an aggregate equation for labour productivity in order to analyse the role of the phenomenon of financialisation on the deceleration of Portuguese labour productivity as a whole. This approach overlooks the potential heterogeneity of labour productivity in different corporations, sectors, industries or regions but allows us to assess whether the phenomenon of financialisation has had a real macroeconomic impact on the slowdown of labour productivity in Portugal. Thus, if we find a statistically significant effect of the aforementioned four channels linked to the phenomenon of financialisation on Portuguese labour productivity, we are unable to conclude if this effect occurs only in a subset of corporations, sectors, industries or regions or if it is a more generalised effect that affects all corporations, sectors, industries or regions. If we do not find a statistically significant effect of the aforementioned four channels linked to the phenomenon of financialisation on Portuguese labour productivity, we cannot exclude that this effect occurs in a subset of corporations, sectors, industries or regions albeit not enough to cause a macroeconomic impact on Portuguese labour productivity as a whole. 


\section{DATA AND STYLISED FACTS}

We collected data for Portugal on a yearly basis from 1980 to 2017, which represents a total sample with 38 observations. This corresponds to the period and the periodicity for which all proxies for our variables are available. The proxy for personal income inequality is only available after 1980 and the proxy for money supply is only available until 2017. The proxies for personal income inequality, money supply and stock market capitalisation are only available on a yearly basis. Note that our sample perfectly covers the period in which the phenomenon of financialisation became more noticeable in Portugal, which occurred since the mid-1980s in the wake of privatisation, liberalisation and deregulation of the Portuguese financial system by the imposition of European rules due to the respective integration process initiated with the adhesion of Portugal to the European Economic Community in 1986 (Barradas et al., 2018).

Due to the complex nature linked to financialisation, we used five different proxies to assess the degree of financialisation, namely credit, money supply, financial value added, stock market capitalisation and shareholder orientation. As emphasised by Barradas (2021), these proxies are those normally used in other empirical works on the role of finance because they reflect different dimensions (e.g., size, depth and efficiency) played by different financial intermediaries (e.g., banks and stock markets) or even by shareholders.

Table 1. The proxies and sources for our variables

\begin{tabular}{|c|c|c|}
\hline Variable & Proxy & Source \\
\hline Labour Productivity & GDP at constant prices per hour worked (growth rate \%) & AMECO \\
\hline Economic Performance & GDP at constant prices (growth rate $\%$ ) & AMECO \\
\hline Labour Income Share & Adjusted labour income share (\% of GDP) & AMECO \\
\hline Personal Income & Top $1 \%$ income share ( $\%$ of total) & World \\
\hline Inequality & & Inequality \\
\hline Credit & Total credit to private non-financial sector (\% of GDP) & Fred St. Louis \\
\hline Money Supply & Liquid liabilities (\% of GDP $)^{5}$ & Fred St. Louis \\
\hline Financial Value Added & Gross value added of financial, insurance and real estate activities ( $\%$ of total) & PORDATA \\
\hline Stock Market & Stock market capitalisation of listed domestic companies (\% of GDP) & World Bank \\
\hline Capitalisation & & \\
\hline Shareholder Orientation & Net financial payments of non-financial corporations ( $\%$ of gross value added) & INE \\
\hline
\end{tabular}

5 According to Fred St. Louis database, "liquid liabilities are also known as broad money, or M3. They are the sum of currency and deposits in the central bank (M0), plus transferable deposits and electronic currency (M1), plus time and savings deposits, foreign currency transferable deposits, certificates of deposit, and securities repurchase agreements (M2), plus travelers checks, foreign currency time deposits, commercial paper, and shares of mutual funds or market funds held by residents". 
Table 1. The descriptive statistics for our variables

\begin{tabular}{|c|c|c|c|c|c|c|c|}
\hline Variable & Mean & Median & Maximum & Minimum & $\begin{array}{l}\text { Standard } \\
\text { Deviation }\end{array}$ & Skewness & Kurtosis \\
\hline Labour Productivity & 0.017 & 0.015 & 0.063 & -0.029 & 0.018 & 0.281 & 3.819 \\
\hline $\begin{array}{c}\text { Economic } \\
\text { Performance }\end{array}$ & 0.021 & 0.020 & 0.079 & -0.041 & 0.026 & -0.004 & 3.189 \\
\hline Labour Income Share & 0.582 & 0.583 & 0.687 & 0.510 & 0.041 & 0.711 & 3.931 \\
\hline $\begin{array}{c}\text { Personal Income } \\
\text { Inequality }\end{array}$ & 0.107 & 0.109 & 0.119 & 0.087 & 0.009 & -0.725 & 2.529 \\
\hline Credit & 1.459 & 1.375 & 2.316 & 0.771 & 0.489 & 0.226 & 1.664 \\
\hline Money Supply & 0.867 & 0.851 & 1.015 & 0.703 & 0.090 & -0.054 & 1.973 \\
\hline $\begin{array}{c}\text { Financial Value } \\
\text { Added }\end{array}$ & 0.140 & 0.137 & 0.181 & 0.097 & 0.028 & -0.018 & 1.816 \\
\hline $\begin{array}{l}\text { Stock Market } \\
\text { Capitalisation }\end{array}$ & 0.248 & 0.270 & 0.551 & 0.003 & 0.165 & 0.053 & 2.043 \\
\hline $\begin{array}{l}\text { Shareholder } \\
\text { Orientation }\end{array}$ & 0.107 & 0.126 & 0.184 & 0.040 & 0.045 & -0.183 & 1.657 \\
\hline
\end{tabular}

Table 2. The correlations between our variables

\begin{tabular}{|c|c|c|c|c|c|c|c|c|c|}
\hline & LP & EP & LIS & PII & $\mathrm{C}$ & MS & FVA & SMC & SO \\
\hline LP & 1.000 & & & & & & & & \\
\hline EP & $0.587 * * *$ & 1.000 & & & & & & & \\
\hline LIS & 0.108 & 0.081 & 1.000 & & & & & & \\
\hline PII & -0.093 & 0.045 & $-0.502 * * *$ & 1.000 & & & & & \\
\hline C & $-0.500 * * *$ & $-0.685^{* * *} *$ & $-0.400 * *$ & 0.073 & 1.000 & & & & \\
\hline MS & $-0.561 * * *$ & $-0.665 * * *$ & $-0.481 * * *$ & 0.269 & $0.923 * * *$ & 1.000 & & & \\
\hline FVA & $-0.325^{* *}$ & $-0.464 * * *$ & $-0.647 * * *$ & $0.513^{* * *}$ & $0.801 * * *$ & $0.832 * * *$ & 1.000 & & \\
\hline SMC & -0.199 & -0.074 & $-0.357 * *$ & $0.588^{* * *}$ & $0.505^{* * * *}$ & $0.570 * * *$ & $0.633^{* * *}$ & 1.000 & \\
\hline So & $-0.358 * *$ & $-0.482 * * *$ & $-0.469 * * *$ & $0.512 * * *$ & $0.789 * * *$ & $0.834 * * *$ & $0.894 * * *$ & $0.783 * * *$ & 1.000 \\
\hline
\end{tabular}

Note: $* * *$ indicates statistical significance at the $1 \%$ level, $* *$ indicates statistical significance at the $5 \%$ level and $*$ indicates statistical significance at the $10 \%$ level 


\section{Figure 1. The plots of our variables}
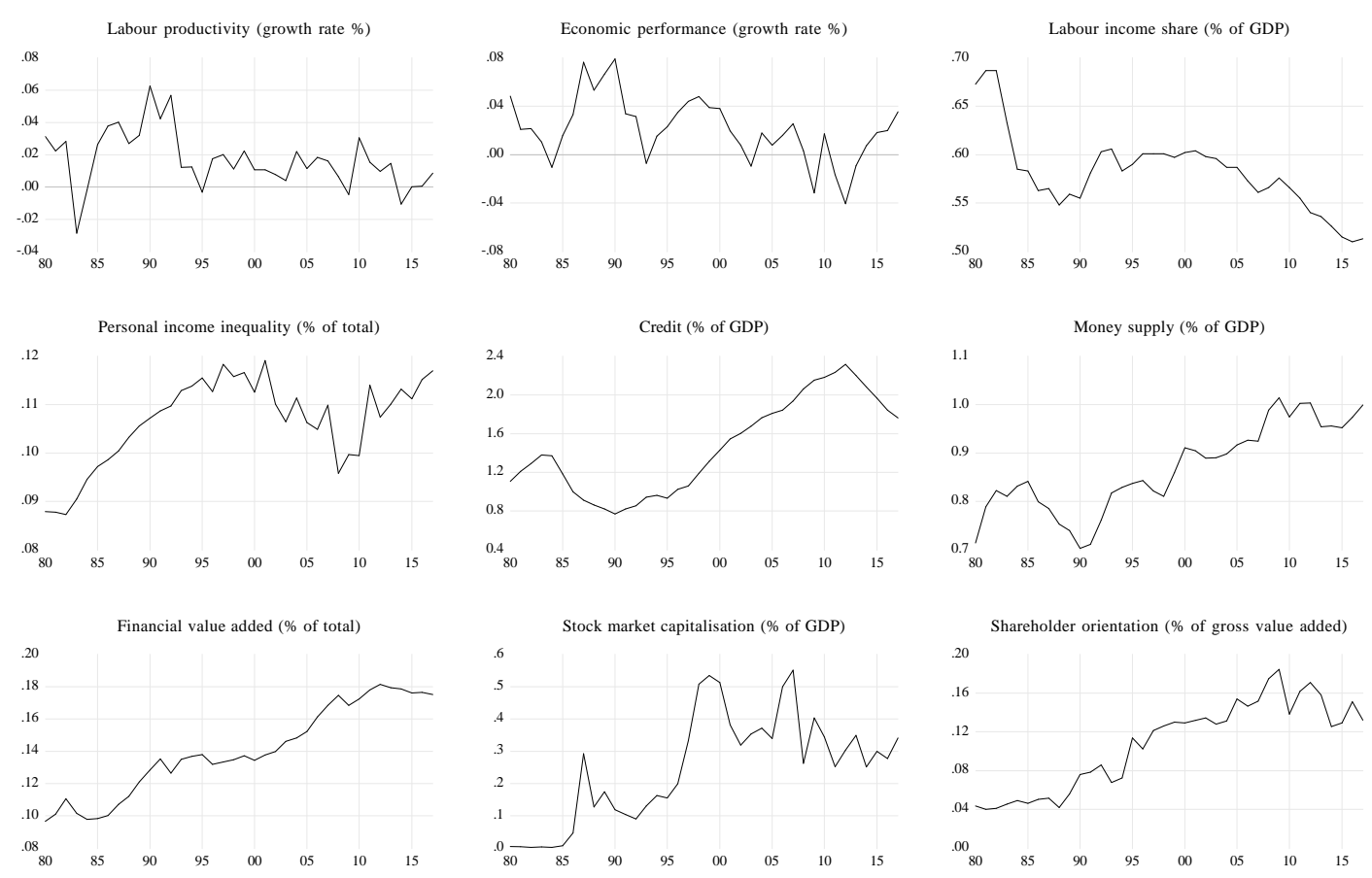

Table 1 describes the proxies and sources for our variables, Table 2 contains the descriptive statistics for our variables, Table 3 exhibits the correlations between our variables and Figure 1 illustrates the plots of our variables. Note that all correlations between our variables are less than 0.8 in absolute terms, which confirms the inexistence of multicollinearity between them (Studenmund, 2005). The only exceptions occur with the correlations between some proxies linked to the degree of financialisation. This is the reason we did not simultaneously use all of these proxies but used them separately from each other. The idea is just to assess if our results are robust according to the proxy for the degree of financialisation selected.

We confirm that the slowdown of labour productivity is a stylised fact in Portugal, particularly after the late 1980s. In the same vein, the deceleration in economic performance, the fall in the labour income share, the rise in personal income inequality and the intensification of the degree of financialisation are also stylised facts in Portugal in the last decades. This is the reason we observe positive correlations between economic performance and labour productivity and between labour income share and labour productivity. This is also the reason we observe negative correlations between personal income inequality and labour productivity and between the degree of financialisation and labour productivity. 


\section{ECONOMETRIC METHOD}

We employed the GMM estimator popularised by Hansen (1982), not only due to the incorporation of lagged labour productivity among our independent variables but also due to the potential existence of endogeneity in our conceptual model for two different reasons ${ }^{6}$. First, we needed to contour endogeneity due to the omission of the aforementioned 'Ricardo effect' (Ricardo, 1821) and/or other important determinants of labour productivity not directly or indirectly related to the phenomenon of financialisation (Fortune, 1987; Vergeer \& Kleinknecht, 2014; Micallef, 2016; Dua \& Garg, 2019; Carnevali et al., 2020; Pariboni and Tridico, 2020; Yousef, 2020). Second, we needed to contour endogeneity due to the possible existence of simultaneity among our different variables (Vergeer \& Kleinknecht, 2014; Carnevali et al., 2020).

The GMM estimator requires the definition of a set of instrumental variables, that is, the so-called instruments. The number of instruments should be greater or equal to the number of independent variables in the conceptual model, and instruments should be exogeneous in relation to the error component and simultaneously strongly correlated with the independent variables (Greene, 2003). The traditional rule of thumb is to choose several lags of the independent variables as instruments. We chose five lags of each independent variable to encompass our set of instruments, which were validated using the J-Statistic proposed by Hansen (1982). The structural stability of our models was assessed by employing the Hall and Sen (1999) O-Statistic.

We used the EViews software (version 11) to produce our estimates. We employed the Newey-West option for the weighting matrix, which is a heteroskedasticity and autocorrelation consistent estimator. In addition, we relapsed on the Barlett Kernel option and on the N-Step Iterative procedure for weighting matrix updating. Note that under suitable conditions, estimates produced by the GMM estimator are consistent, asymptotically normal and asymptotically efficient (Hansen, 1982).

We also present the economic effects of our statistically significant estimates (McCloskey and Ziliak, 1996; Ziliak and McCloskey, 2004) in order to assess the contribution of each of the aforementioned four channels linked to the phenomenon of financialisation to the slowdown of labour productivity in Portugal in the last decades.

\footnotetext{
${ }^{6}$ Note that we assume that all variables are stationary in levels due to three different reasons. Firstly, the unit root tests have low power and perform very poorly in the presence of small samples (Greene, 2003), which is our case. Secondly, our variables are already expressed in growth rates or in ratios. Thirdly, the plots of our variables (Figure 1) seem to suggest that all variables are stationary in levels.
} 


\section{EMPIRICAL RESULTS AND DISCUSSION}

Our estimates for Portuguese labour productivity are presented in Table 4. We produced our estimates by using five different models. Each model used a different proxy for the variable related to the degree of financialisation. All five of these models describe relatively well the evolution of labour productivity in Portugal in the last decades, taking into account the high Rsquared and adjusted R-squared values, respectively. Note that around 60\% (50\%) of the evolution of Portuguese labour productivity in the last decades is explained by our models. All five of these models are suitable and our set of instruments are valid, taking into account that we do not reject the null hypothesis of the J-Statistic for any of them. Our estimates and instruments are also stable over time and we do not detect the existence of structural breaks, knowing that we do not reject the null hypothesis of the Hall and Sen (1999) O-Statistic for any of our 5 models ${ }^{7}$.

All variables are statistically significant at the conventional significance levels and have the expected signs for all five of the models that were considered. This confirms the robustness of our results because our estimates do not change in terms of statistical significance and signs between the different models. The only exception occurs with the variable of labour income share which loses statistical significance for the models when we add money supply and financial value as proxies for the degree of financialisation.

Lagged labour productivity is a positive determinant of labour productivity in Portugal, which confirms that this variable is indeed relatively persistent (Vergeer and Kleinknecht, 2014). Economic performance also positively impacts labour productivity in Portugal, which confirms the 'Smith effect' (1776) or the 'Classical Kaldorian-Verdoorn effect' (Verdoorn, 1949; Kaldor, 1961). A similar result was found by Tridico and Pariboni (2018) for 26 countries in the OECD (Australia, Austria, Belgium, Canada, Chile, Denmark, Finland, France, Germany, Greece, Iceland, Israel, Italy, Japan, Luxembourg, Mexico, the Netherlands, New Zealand, Norway, Portugal, the Republic of Korea, Spain, Sweden, Switzerland, the UK and the US) and by Carnevali et al. (2020) for eight countries of the euro area (Austria, France, Greece, Germany, Italy, the Netherlands, Portugal and Spain). The labour income share also exerts a positive influence on labour productivity in Portugal which is in line with the predictions of the 'WebbSylos Labini effect' (Labini, 1984, 1999) or 'the Marx and Hicks effect' (Hein and Tarassow, 2010). A positive relationship between labour income share and labour productivity was also reported by Vergeer and Kleinknecht (2014) for 20 countries in the OECD (Australia, Austria, Belgium, Canada, Denmark, Finland, France, Germany, Ireland, Italy, Japan, the Netherlands, New Zealand, Norway, Portugal, Spain, Sweden, Switzerland, the UK and the US) and by Tridico

\footnotetext{
${ }^{7}$ Please note that the results of the Hall and Sen (1999) O-Statistic are available upon request.
} 
and Pariboni (2018), Carnevali et al. (2020) and Yousef (2020) for Jordan. Personal income inequality and the degree of financialisation also determine labour productivity in Portugal by exerting a negative effect ${ }^{8}$. A negative impact from personal income inequality and the degree of financialisation on labour productivity was also stated by Tridico and Pariboni (2018).

Table 3. Estimates of Portuguese labour productivity

\begin{tabular}{|c|c|c|c|c|c|}
\hline Variable & Credit & Money Supply & $\begin{array}{c}\text { Financial Value } \\
\text { Added }\end{array}$ & $\begin{array}{l}\text { Stock Market } \\
\text { Capitalisation }\end{array}$ & $\begin{array}{c}\text { Shareholder } \\
\text { Orientation }\end{array}$ \\
\hline$\beta_{0}$ & $\begin{array}{c}0.086^{* * * *} \\
(0.012) \\
{[6.883]}\end{array}$ & $\begin{array}{c}0.187 * * * \\
(0.019) \\
{[9.968]}\end{array}$ & $\begin{array}{c}0.096^{* * * *} \\
(0.015) \\
{[6.183]}\end{array}$ & $\begin{array}{c}0.067 * * * \\
(0.009) \\
{[7.806]}\end{array}$ & $\begin{array}{c}0.073 * * * \\
(0.011) \\
{[6.588]}\end{array}$ \\
\hline$L P_{t-1}$ & $\begin{array}{c}0.308 * * * \\
(0.032) \\
{[9.545]}\end{array}$ & $\begin{array}{c}0.158 * * * \\
(0.024) \\
{[6.513]}\end{array}$ & $\begin{array}{c}0.323 * * * \\
(0.026) \\
{[12.292]}\end{array}$ & $\begin{array}{c}0.288 * * * \\
(0.033) \\
{[8.675]}\end{array}$ & $\begin{array}{c}0.307 * * * \\
(0.026) \\
{[11.904]}\end{array}$ \\
\hline$E P_{t}$ & $\begin{array}{c}0.289 * * * \\
(0.032) \\
{[9.141]}\end{array}$ & $\begin{array}{l}0.098 * * \\
(0.045) \\
{[2.198]}\end{array}$ & $\begin{array}{c}0.246^{* * *} * \\
(0.048) \\
{[5.117]}\end{array}$ & $\begin{array}{c}0.253^{* * * *} \\
(0.029) \\
{[8.590]}\end{array}$ & $\begin{array}{c}0.219 * * * \\
(0.030) \\
{[7.404]}\end{array}$ \\
\hline$L I S_{t}$ & $\begin{array}{l}0.044 * * \\
(0.017) \\
{[2.617]}\end{array}$ & $\begin{array}{l}-0.025 \\
(0.018) \\
{[-1.373]}\end{array}$ & $\begin{array}{l}0.027 \\
(0.025) \\
{[1.103]}\end{array}$ & $\begin{array}{c}0.079 * * * \\
(0.013) \\
{[5.875]}\end{array}$ & $\begin{array}{c}0.040 * * * \\
(0.013) \\
{[3.035]}\end{array}$ \\
\hline$P I I_{t}$ & $\begin{array}{c}-0.927 * * * \\
(0.062) \\
{[-15.059]}\end{array}$ & $\begin{array}{c}-0.732 * * * \\
(0.042) \\
{[-17.365]}\end{array}$ & $\begin{array}{c}-0.885^{* * *} \\
(0.135) \\
{[-6.236]}\end{array}$ & $\begin{array}{c}-0.897 * * * \\
(0.070) \\
{[-12.883]}\end{array}$ & $\begin{array}{c}-0.745^{* * *} \\
(0.085) \\
{[-8.764]}\end{array}$ \\
\hline$D F_{t}$ & $\begin{array}{l}-0.002 * \\
(0.001) \\
{[-1.980]}\end{array}$ & $\begin{array}{c}-0.091 * * * \\
(0.010) \\
{[-9.082]}\end{array}$ & $\begin{array}{c}-0.084 * * \\
(0.040) \\
{[-2.078]}\end{array}$ & $\begin{array}{c}-0.022 * * * \\
(0.003) \\
{[-6.422]}\end{array}$ & $\begin{array}{c}-0.063 * * * \\
(0.015) \\
{[-4.321]}\end{array}$ \\
\hline R-Squared & 0.588 & 0.609 & 0.583 & 0.594 & 0.585 \\
\hline Adjusted R ${ }^{2}$ & 0.511 & 0.537 & 0.506 & 0.519 & 0.508 \\
\hline J-Statistic & 8.586 & 8.414 & 8.324 & 8.670 & 8.515 \\
\hline J-Statistic (P-Value) & 0.987 & 0.989 & 0.989 & 0.986 & 0.988 \\
\hline
\end{tabular}

\footnotetext{
${ }^{8}$ Please note that this negative impact of personal income inequality on labour productivity in Portugal does not change if we use the top $10 \%$ income share instead of the top $1 \%$ income share. Results are available upon request.
} 
These results seem to suggest that the evolution of labour productivity in Portugal has been clearly affected by the aforementioned four channels linked to the phenomenon of financialisation. The role of each of these four channels on that evolution is exhibited in Table 5 and in Table 6 in which we present the respective economic effects. Table 5 exhibits the economic effect of each channel on each one of the five models and Table 6 contains the average economic effect of each channel on all five models.

Table 4. Economic effects on Portuguese labour productivity

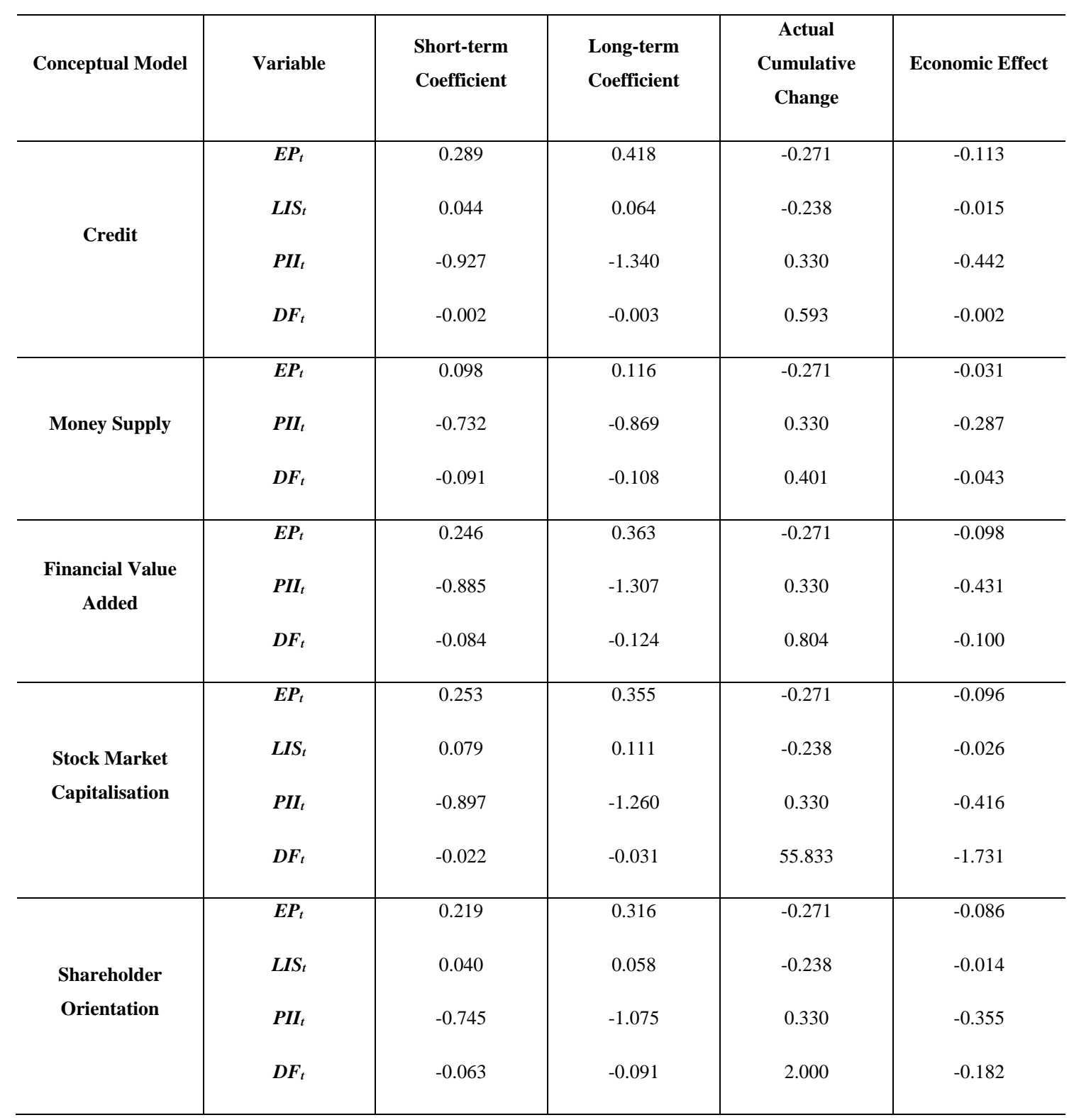

Note: The long-term coefficient is obtained through the ratio between the short-term coefficient (estimated coefficient) and one minus the coefficient of the autoregressive estimation (estimated lagged labour productivity coefficient). The actual cumulative change corresponds to the growth rate of the correspondent variable. The economic effect is the multiplication of the long-term coefficient by the actual cumulative change 
Table 5. Average of the economic effects on Portuguese labour productivity

\begin{tabular}{|c|c|c|}
\hline Variable & Actual Cumulative Change & Economic Effect (Average) \\
\hline$\overline{E P_{t}}$ & -0.271 & -0.085 \\
\hline$L I S_{t}$ & -0.238 & -0.018 \\
\hline$P I I_{t}$ & 0.330 & -0.386 \\
\hline$D F_{t}$ & n.a. & -0.412 \\
\hline
\end{tabular}

Note: The actual cumulative change of the degree of financialisation is not available (n.a.) because it corresponds to the growth rate of the five different variables (credit, money supply, financial value added, stock market capitalisation and shareholder orientation)

The most important finding is that all four of the aforementioned channels linked to the phenomenon of financialisation have been detrimental to the evolution of labour productivity in Portugal given the corresponding negative economic effects of each one. In effect, the deceleration in economic performance, the fall in labour income share, the rise of personal income inequality and the intensification of the degree of financialisation have contributed to deceleration of labour productivity in Portugal from 1980 to 2017 by approximately on average 8.5 percent, 1.8 percent, 38.6 percent and 41.2 percent, respectively ${ }^{9}$. The intensification of the degree of financialisation and the rise of personal income inequality were the main triggers of the deceleration of labour productivity in Portugal in the last decades.

\section{CONCLUSION}

The aim of this paper was to conduct a time series econometric analysis in order to empirically evaluate the role of financialisation in the slowdown of labour productivity in Portugal in the period from 1980 to 2017.

From a theoretical point of view and following the post-Keynesian literature, the phenomenon of financialisation has contributed to the slowdown of labour productivity in more advanced economies in the last decades, which has occurred through four different channels (Tridico and Pariboni, 2018), notably weak economic performance, a fall in the labour income share, a rise in personal income inequality and the intensification of the degree of financialisation.

\footnotetext{
${ }^{9}$ Note that the average economic effect of the degree of financialisation is particularly high (41.2 percent) due to the stronger economic effect of the degree of financialisation in the conceptual model with the proxy of stock market capitalisation (173.1 per cent).
} 
Accordingly, we estimated an aggregate equation according to which labour productivity depends on lagged labour productivity, economic performance, the labour income share, the level of personal income inequality and the degree of financialisation. We employed the GMM estimator popularised by Hansen (1982) due to the inclusion of lagged labour productivity among the independent variables and to contour the potential problem of endogeneity that arises when there are problems with omitted variables and/or simultaneity.

Our results confirm that lagged labour productivity, economic performance and labour income share exert a positive impact on labour productivity in Portugal, whereas personal income inequality and the degree of financialisation exert a negative impact on labour productivity in Portugal. This confirms that these four channels linked to the phenomenon of financialisation have been important drivers of the slowdown of labour productivity in Portugal in a context in which the intensification of the degree of financialisation and the rise of personal income inequality have been the main triggers for that evolution.

Our results also suggest the need to engage in policies to promote the phenomenon of definancialisation of the Portuguese economy in the coming years. This is required to support stronger economic performance, an increase in the labour income share, a decrease in personal income inequality, a reduction in the degree of financialisation and, consequently, an acceleration of Portuguese labour productivity. The policy recommendations proposed by Palley (2007), Hein (2012), Vercelli (2013) and Sawyer (2015) could represent some directions that Portuguese policymakers could follow to ensure the phenomenon of de-financialisation in the coming years.

Further research on labour productivity in Portugal should use micro data to assess the role of these four channels linked to the phenomenon of financialisation at the corporate level, the sector level, the industry level or the regional level. This approach will allow a determination of whether or not these detrimental effects of the phenomenon of financialisation on the slowdown of labour productivity has affected all corporations, sectors, industries or regions in the same manner and/or to the same degree.

\section{REFERENCES}

Aghion, P., Howitt, P., and Mayer-Foulkes, D. (2005). The Effect of Financial Development on Convergence: Theory and Evidence, Quarterly Journal of Economics, 120 (1), 173-222.

Akkemik, K. A., and Özen, Ş. (2014). Macroeconomic and institutional determinants of financialisation of non-financial firms: Case study of Turkey, Socio-Economic Review, 12 (1), $71-98$. 
Altman, M. (1998). A High-Wage Path to Economic Growth and Development, Challenge, 41 (1), 91-104.

Alvarez, I. (2015). Financialisation, non-financial corporations and income inequality: the case of France, Socio-Economic Review, 13 (3), 449-475.

Ang, J. B. (2008). A Survey of Recent Developments in the Literature of Finance and Growth, Journal of Economic Surveys, 22 (3), 536-576.

Banerjee, A. V., and Newman, A. F. (1993). Occupational Choice and the Process of Development, Journal of Political Economy, 101 (2), 274-298.

Barajas, A., Chami, R., and Yousefi, S. R. (2013). The Finance and Growth Nexus Re-Examined: Do All Countries Benefit Equally?, IMF Working Paper 13/130.

Barradas, R. (2016). Evolution of the Financial Sector - Three Different Stages: Repression, Development and Financialisation. In Gomes, O. and Martins, H. F. (ed.). Advances in Applied Business Research: the L.A.B.S. Initiative: New York: Nova Science Publishers.

Barradas, R. (2017). Financialisation and Real Investment in the European Union Beneficial or Prejudicial Effects?, Review of Political Economy, 29 (3), 376-413.

Barradas, R. (2019). Financialisation and Neoliberalism and the Fall in the Labour Share: A Panel Data Econometric Analysis for the European Union Countries, Review of Radical Political Economics, 51 (3), 383-417

Barradas, R. (2020). Does the financial system support economic growth in times of financialisation: Evidence for Portugal, International Review of Applied Economics, 34 (6), 785806.

Barradas, R., and Lagoa, S. (2017). Financialisation and Portuguese real investment: A supportive or disruptive relarionship?, Journal of Post Keynesian Economics, 40 (3), 413-439.

Barradas, R., and Lagoa, S. (2017). Functional Income Distribution in Portugal: The Role of Financialisation and Other Related Determinants, Society and Economy, 39 (2), 183-212.

Barradas, R., Lagoa, S., Leão, E., and Mamede, R. P. (2018). Financialisation in the European Periphery and the Sovereign Debt Crisis: The Portuguese Case, Journal of Economic Issues, 52 (4), 1056-1083.

Baud, C., and Durand, C. (2012). Financialization, globalization and the making of profits by leading retailers, Socio-Economic Review, 10 (2), 241-266. 
Beck, T., Degryse, H., and Kneer, C. (2014), Is more finance better? Disentangling intermediation and size effects of financial systems, Journal of Financial Stability, 10 (1), 50-64.

Breitenlechner, M., Gächter, M., and Sindermann, F. (2015). The finance-growth nexus in crisis, Economics Letters, 132 (1), 31-33.

Carnevali, E., Godin, A., Lucarelli, S., and Passarella, M. V. (2020), Productivity growth, Smith effects and Ricardo effects in Euro Area's manufacturing industries, Metroeconomica, 71 (1), $129-155$.

Cordonnier, L., and Van de Velde, F. (2014). The demands of finance and the glass ceiling of profit without investment, Cambridge Journal of Economics, 39 (3), 871-885.

Crotty, J. R. (2005). The Neoliberal Paradox: The Impact of Destructive Product Market Competition and Impatient Finance on Nonfinancial Corporations in the Neoliberal Era. In Epstein, A. (ed.), Financialisation and the World Economy. Cheltenham: Edward Elgar Publishing Limited.

Dabla-Norris, E., and Srivisal, N. (2013). Revisiting the Link Between Finance and Macroeconomic Volatility, IMF Working Paper 13/29.

Davis, L. (2017). Financialization and the non-financial corporation: An investigation of firmlevel investment behavior in the United States, Metroeconomica, 69 (1), 270-307.

Dua, P., and Garg, N. K. (2019). Determinants of labour productivity: Comparison between developing and developed countries of Asia-Pacific, Pacific Economic Review, 24 (5), 686-704.

Ehigiamusoe, K. U., and Lean, H. H. (2018). Finance-Growth Nexus: New Insights from the West African Region, Emerging Markets Finance and Trade, 54 (11), 2596-261.

Fortune, J. N. (1987). Some determinants of labour productivity, Applied Economics, 19 (6), 839843.

Galor, O., and Zeira J. (1993). Income Distribution and Macroeconomics, The Review of Economic Studies, 60 (1), 35-52.

Gehrke, C. (2003). The Ricardo Effect: Its Meaning and Validity, Economica, 70 (277), 143-158.

Gimet, C., and Lagoarde-Segot, T. (2011). A closer look at financial development and income distribution, Journal of Banking and Finance, 35 (7), 1698-1713.

Greene, W. H. (2003). Econometric Analysis. $5^{\text {th }}$ Edition. Prentice-Hall: New York University.

Greenwood, J., and Jovanovic, B. (1990). Financial Development, Growth, and the Distribution of Income, Journal of Political Economy, 98 (5), 1076-1107. 
Hall, A. R., and Sen, A. (1999). Structural Stability Testing in Models Estimated by Generalized Method of Moments, Journal of Business and Economic Statistics, 17 (3), 335-348.

Hansen, L. P. (1982). Large Sample Properties of Generalized Method of Moments Estimators, Econometrica, 50 (4), 1029-1054.

Hein, E. (2010). 'Financialisation', Capital Accumulation and Productivity Growth: a PostKeynesian Approach. In Fontana, G., McCombie, J., and Sawyer, M. (ed.) Macroeconomics, Finance and Money. Palgrave Macmillan.

Hein, E. (2012). The Macroeconomics of Finance-dominated Capitalism - and its Crisis. Cheltenham: Edward Elgar Publishing Limited.

Hein, E., and Tarassow, A. (2010). Distribution, aggregate demand and productivity growth: theory and empirical results for six OECD countries based on a post-Kaleckian model, Cambridge Journal of Economics, 34 (4), 727-754.

Hein, E., and Van Treeck, T. (2010). 'Financialisation' in Post-Keynesian models of distribution and growth. In M. Setterfield (ed.) Handbook of Alternative Theories of Economic Growth. Cheltenham: Edward Elgar Publishing Limited.

Kaldor, N. (1957). A Model of Economic Growth, The Economic Journal, 67 (268), 591-624.

Kaldor, N. (1961). Capital Accumulation and Economic Growth. In Lutz, F. A. and Hague, D. C. (eds.) The Theory of Capital. New York: St. Martin's Press.

Kalecki, M. (1937). The Principle of Increasing Risk, Economica, 4 (16), 440-447.

Kohler, K., Guschanski, A., and Stockhammer, E. (2019). The impact of financialisation on the wage share: a theoretical clarification and empirical test, Cambridge Journal of Economics, 43 (4), 937-974.

Kristal, T. (2010). Good times, bad times. Postwar Labour's Share of National Income in Capitalist Democracies, American Sociological Review, 75 (5), 729-763.

Labini, P. S. (1984). The Forces of Economic Growth and Decline. Cambridge: MIT Press.

Labini, P. S. (1999). The Employment Issue: Investment, Flexibility and the Competition of Developing Countries, PSL Quarterly Review, 52 (10), 257-280.

Lagoa, S., and Barradas, R. (2020). Financialisation and Inequality in the Semi-Periphery: Evidence from Portugal. In Santos, A. C. and Teles, N. (eds.) Financialisation in the European Periphery: Work and Social Reproduction in Portugal. London: Routledge. 
Lazonick, W., and O'Sullivan, M. (2000). Maximising shareholder value: a new ideology for corporate governance, Economic and Society, 29 (1), 13-35.

Levine, R. (1997). Financial Development and Economic Growth: Views and Agenda, Journal of Economic Literature, 35 (2), 688-726.

Lin, K., and Tomaskovic-Devey, D. (2013). Financialisation and US Income Inequality, 1970 2008, American Journal of Sociology, 118 (5), 1284-1329.

Marshall, A. (1890). Principles of Economics. London: MacMillan.

McCloskey, D. N., and Ziliak, S. T. (1996). The Standard Error of Regressions, Journal of Economic Literature, 34 (1), 97-114.

Micallef, B. (2016). Determinants of Labour Productivity in Malta: Evidence from a Firm-Level Survey, Economics and Sociology, 9 (4), 27-40.

Onaran, Ö., and Obst, T. (2016). Wage-led growth in the EU15 member-states: the effects of income distribution on growth, investment, trade balance and inflation, Cambridge Journal of Economics, 40 (6), 1517-1551.

Onaran, Ö., Stockhammer, E., and Grafl, L. (2011). Financialisation, income distribution and aggregate demand in the USA, Cambridge Journal of Economics, 35 (4), 637-661.

Orhangazi, Ö. (2008). Financialisation and capital accumulation in the non-financial corporate sector: A theoretical and empirical investigation on the US economy: 1973-2003, Cambridge Journal of Economics, 32 (6), 863-886.

Palley, T. I. (2007). Financialisation: What it is and Why it Matters?, Political Economy Research Institute Working Paper, 153.

Pariboni, R., and Tridico, R. (2020). Structural change, institutions and the dynamics of labor productivity in Europe, Journal of Evolutionary Economics, 30 (1), 1275-1300.

Ricardo, D. (1821). On the Principles of Political Economy and Taxation. New York: John Murray, Albemarle-Street.

Rioja, F., and Valev, N. (2004a). Finance and the Sources of Growth at Various Stages of Economic Development, Economic Inquiry Journal, 42 (1), 127-140.

Rioja, F., and Valev, N. (2004b). Does one size fit all? A reexamination of the finance and growth relationship. Journal of Development Economics, 74 (1), 429-447.

Roine, J., Vlachos, J., and Waldenströrm, D. (2009). The long-run determinants of inequality: What can we learn from top income data?, Journal of Public Economics, 93(7-8), 974-988. 
Rousseau, P. L., and Wachtel, P. (2011). What is happening to the impact of financial deepening on economic growth?, Economic Inquiry, 49 (1), 276-288.

Samuel, C. (2000). Does Shareholder Myopia Lead to Managerial Myopia? A First Look, Applied Financial Economics, 10 (5), 493-505.

Sawyer, M. (2015). Financialisation, financial structures, economic performance and employment, FESSUD Working Paper, 93.

Seo, H. J., Kim, H. S., and Kim, Y. C. (2012). Financialization and the Slowdown in Korean Firms’ R\&D Investment, Asian Economic Papers, 11 (3), 35-49.

Smith. A. (1776). The Wealth of Nations. London: Edward Elgar Publishing Limited.

Soener, M. C. (2015). Why do firms financialize? Meso-level evidence from the US apparel and footwear industry, 1991-2005, Socio-Economic Review, 13 (3), 549-573.

Stockhammer, E. (2004). Financialisation and the slowdown of accumulation, Cambridge Journal of Economics, 28 (5), 719-741.

Stockhammer, E. (2006). Shareholder value orientation and the investment-profit puzzle, Journal of Post Keynesian Economics, 28 (2), 193-215.

Stockhammer, E. (2017). Determinants of the Wage Share: A Panel Data Analysis of Advanced and Developing Economies, British Journal of Industrial Relations, 55 (1), 3-33.

Studenmund, A. H. (2005). Using Econometrics: A Practical Guide. $5^{\text {th }}$ Edition, Boston: Addison Wesley Pearson.

Tori, D., and Onaran, Ö. (2018). The effects of financialization on investment: evidence from firm-level data for the UK, Cambridge Journal of Economics, 42 (5), 1393-1416.

Tori, D., and Onaran, Ö. (2019). Financialization, financial development and investment. Evidence from European non-financial corporations, Socio-Economic Review, 18 (3), 681-718.

Tridico, P., and Pariboni, R. (2018). Inequality, financialization, and economic decline, Journal of Post Keynesian Economics, 41 (2), 236-259.

Van Treeck, T. (2008). Reconsidering the Investment-Profit Nexus in Finance-Led Economies: an ARDL-Based Approach, Metroeconomica, 59 (3), 371-404.

Vercelli, A. (2013). Financialisation in a Long-Run Perspective, International Journal of Political Economy, 42 (4), 19-46. 
Vergeer, R., and Kleinnknecht, A. (2014). Do labour market reforms reduce labour productivity growth? A panel data analysis of 20 OECD countries (1960-2004), International Labour Review, $153(3), 365-393$.

Yousef, E. M. M. A. (2020). The Determinants of Labor Productivity in Jordan During the Period 1980-2017, International Journal of Business and Economic Research, 9 (1), 21-28.

Verdoorn, P. J. (2002). Fattori che regolano lo sviluppo della produttività del lavoro, L'industria, $1(1), 3-10$.

Webb, S. (1912). The Economic Theory of a Legal Minimum Wage, Journal of Political Economy, 20 (10), 973-998.

Ziliak, S. T., and McCloskey, D. N. (2004). Size matters: the standard error of regressions in the American Economic Review, The Journal of Socio-Economics, 33 (5), 527-554. 